\title{
TXK Gene
}

National Cancer Institute

\section{Source}

National Cancer Institute. TXK Gene. NCI Thesaurus. Code C162444.

This gene plays a role in the regulation of adaptive immune responses. 